Author's copy. The article has been published in Environment and Planning D: Society and Space, doi:10.1177/0263775816654916. For citation, please use the original.

\title{
Shaping subjects in everyday encounters: Intergenerational recognition in intersubjective socialisation
}

\author{
Abstract: \\ This article considers the role of intergenerational recognition in processes of subject \\ formation and political development. It leans on a broad conception of politics, following \\ a phenomenologically oriented approach and drawing from theories of contextual \\ recognition. Intergenerational recognition is introduced as a key dynamism and practice \\ in intersubjective socialisation, unfolding in everyday environments among 'significant \\ others'. In these encounters, people take shape and are shaped as political subjects. \\ Empirically, the paper is based on research with 129 eleven- to fifteen-year-old girls and \\ boys, including an analysis of their place-based biographies. By introducing different \\ forms of intergenerational (mis)recognition, it shows how the formation of political \\ subjects takes place in the most mundane environments where children and young people \\ lead their lives. In conclusion, the paper suggests that 'political becoming' deserves \\ increasing attention in critical research and intergenerational recognition ought to be \\ better identified as a social practice. Whether intentional or intuitive, the ways in which \\ adults regard children and young people has both harmful and beneficial effects on the \\ formation of their political subjectivities.
}




\section{Introduction}

Some twenty years ago, Erik Ringmar (1996) explored the Swedish intervention in the Thirty Years' War, bringing together insights from international relations and cultural studies traditions. Leaning on a recognition-theoretical framework, he came to the conclusion that we can develop interests and take part in some-things only as some-ones, referring to individual as well as collective political activities. In a similar fashion, feminist political geographer Lynn Staeheli (2008) has noted more recently that political subjectivities are the condition of and prerequisite for any political thought, claimsmaking and action. Both notions represent a rare perspective that places the subject of political action at the centre of enquiry, instead of issues at stake, performed deeds or effects of certain activities.

Adopting this perspective, the present article sets out to shed light on the role of intergenerational recognition in subject formation and political development. The analysis focuses on subjects who may develop interests in some-things and engage in political thought, claims-making and action, on account of their subjectivities as someones, now and in the future. By analysing intimate experiences of children and youths in the most mundane contexts of everyday life, I call forth fleeting moments and dynamic relations in which political subjects take shape and are shaped during the early years. Contrary to traditional studies of political socialisation, the analysis is based on an intersubjective conception of political development (e.g. Connell, 1987; Crossley, 2001; Hollway, 2006; Habashi and Worley, 2009; Elwood and Mitchell, 2012). In my research on political agency, I have worked to develop an approach that acknowledges children's 
active roles in the dynamic processes of political formation, namely intersubjective socialization (e.g. Kallio, 2007, 2014a; Kallio and Häkli, 2011, 2013).

The study behind this paper has explored youthful political agencies by learning with and from children and young people about their everyday worlds and about themselves as experiencers in these worlds. Leaning on a broad understanding of politics 'as a form of activity concerned with addressing problems of living together in a shared world of plurality and difference' (Barnett, 2012: 679), the research follows a phenomenologically oriented geographical reading of Hannan Arendt's $(1958,2005)$ philosophy (cf. Dikeç, 2013; Baines 2015, for the Merleau-Pontian tradition that has a slightly different take on phenomenology, see Simonsen, 2013). The perspective employed, drawing also on Mead's pragmatist thought (1934), emphasises that people's conditioned yet subjective relations with each other define how things are political in a given spatio-temporal realm, or 'polis', where they lead their lives (Häkli and Kallio, 2014). In addition to these political-philosophical starting points, the analysis makes use of some ideas developed in contextuality-driven recognition-theoretical research (e.g. Markell, 2007; Noble, 2009; also Kallio, 2014b).

The paper begins with a brief description of the research project. This is followed by an introduction to the theoretical starting points and the methodological approach, where I present an Arendtian reading of the political subject and the spatialities of political life, and portray the idea of contextual recognition including the analytically substantial distinction between subjectivity- and identity-based recognition. After these I turn to the analysis that discusses, first, how intergenerational recognition works as a dynamic force in intimate relations, and second, its role in public encounters. The article ends with 
concluding thoughts about the role of intergenerational recognition in the dynamisms of intersubjective socialisation where political subjects 'take shape', followed by some suggestions for further research.

\section{Exploring political formation through everyday experiences}

The paper is based on research accomplished in two recent and ongoing research projects ${ }^{\mathrm{i}}$. Empirically, it draws from a sub-study carried out with 129 eleven- to fifteenyear-old participants in Helsinki and Tampere, Finland, in 2012 (for previous results, see Kallio, 2014a, 2014b, 2016a, 2016b; Kallio et al., 2015). The fieldwork, done by myself and Elina Stenvall, took place in four fifth and three ninth grade classes, following the spirit of 'critical documentary ethnography' as outlined by Sherry Ortner (2002). Compared with traditional ethnographic projects, this anthropologically oriented approach enters people's lived worlds through dialogically produced biographies with less emphasis on participatory observation. We chose this tactic for three reasons.

First, it is challenging, if not impossible, to follow people around in their everyday environments to witness critical moments in their political formation. Second, to comprise variability, we wanted to involve a large number of participants within a reasonable timeframe, which contrasts with in-depth ethnographic work in which participant observation plays a major part. Third, as we are particularly interested in matters important to the children and young people themselves, contextual child- and youth-led conversations appeared as a suitable method for getting access to experiential politics. 
The fieldwork consisted of autobiographical mapping and story-telling exercises and child/youth-led individual interviews. We began by creating personalised maps that helped the participants to portray their worlds to us. In the interviews-or chats-we used these maps as starting points in generating place-based biographies with them. These child/youth-led conversations aimed at making explicit their meaningful spatial attachments, personal lived-world experiences and attitudes towards matters that seem important in these worlds. They were followed by a story-telling exercise that provided the participants with the opportunity to specify and complete their biographies free from the demands of direct social interaction.

Together the collected materials (maps, recorded and transcribed chats, stories and drawings) provide thick descriptions about the participants' experiential worlds. I consider these dialogically produced materials 'partial truths' influenced by and formulated in the research practice, in the spirit of situated knowledge (e.g. Rose, 1997; Leitner and Sheppard, 2009). This means that they have not been analysed as complete biographies but rather as portrayals of their lived worlds—ones that they wanted to share with us. This theoretically informed methodological choice follows child-centred research ethics. ${ }^{\text {ii }}$

In the analysis, I have approached the participants' lifeworlds as contexts of intersubjective socialisation where they take shape and are shaped as political subjects; or using the Meadian concept, become 'intersubjects' (cf. Crossley, 2001). In a recognitiontheoretical framework, encounters with 'significant others' are seen as potential situations in which children and young people come to understand new things about their worlds and themselves, and may reflect upon these experiences from their subjective stances. 
With its emphasis on intergenerationality, this article concentrates on encounters with adults.

I wish to underline that this paper's focus on political formation and development, or political becoming, is an informed choice. The interdisciplinary discussions on children's politics have thus far paid more attention to political being (e.g. Kjørholt, 2002; Bosco, 2010; Marshall, 2015). This emphasis follows from the dominant childhood studies paradigm that for the past couple of decades has strongly emphasised children's agency in the present (for thorough discussions, see Uprichard, 2008; Strandell, 2010). This paper does not undermine the significance of their acts in or for the present but seeks to enrich the literature where it is the thinnest, answering the call put forward by Mitchell and Elwood (2013: 34):

[T] he interpretive emphasis on witnessing and participating in quotidian events can give a particular bias to the importance of the present. Because it is possible to act in the present, and for researchers to observe and even participate in those actions, it can be given undue weight in studies of political formation. [...] A particular problem with conceptualisations of action-oriented children's politics which foreground the agency or affective experiences of children in the immediate moment, is that they often lack an opening or appreciation for historical and/or futurist modes of thinking, relating or imagining. This makes it possible to elide longer term, intergenerational and/or structurating processes that often have great importance in children's lives and in their political formation. 


\section{Arendtian subject in the politics of coexistence and association}

I find Hannah Arendt's work helpful in unearthing the fundamentally political nature of intersubjective socialisation. It includes a thorough investigation of the subject that pays specific attention to the difference between identities and subjectivities and provides starting points for relational theorization of the spatialities of political life. In one of her best known books, Human Condition, also known as Vita Activa, Arendt (1958: 181) ponders on the identity-subjectivity division:

The manifestation of who the speaker and doer unexchangeably is, though it is plainly visible, retains a curious intangibility that confounds all efforts toward unequivocal verbal expression. The moment we want to say who somebody is, our very vocabulary leads us astray into saying what he is; we get entangled in a description of qualities he necessarily shares with others like him; we begin to describe a type or a 'character' in the old meaning of the word, with the result that his specific uniqueness escapes us.

The major point Arendt makes in this argument is that linguistic categorisations always lose something vital to people's political existence (see also Kallio, 2014c). This ineffable aspect of humanity is the uniqueness of subjects. From the moment of birth, until the time of death, we are distinctive beings who-no matter how similar to some other people-are never identical with each other ${ }^{\mathrm{iii}}$ (Arendt, 1958: 8). To understand how this notion fully reframes the idea of socialisation, it is useful to briefly visit Arendt's conception of political action and its spatial dimensions (for a thorough description, see Kallio, 2014b). 
To Arendt (2005: 113), politics is about 'beginnings' made by people through active living in the presence of others. By beginning something new, people establish themselves in the 'space of appearance', which is the realm of politics where practice and thought interweave (Arendt, 1958: 176, 199). As a constitutive force, this characteristic contains the potential for social change as every human being owns the capacity to beginnings. The flow of beginnings is reliant upon new subjects who enter, conceive of and act in their lived worlds from particular stances and, by so doing, maintain and reconstitute these political realities together with others (Arendt, 1953:301) ${ }^{\mathrm{i}}$. The uniqueness of human subjects opens the horizon of unpredictability: anyone may take their world by surprise and thus act as an agent of change.

This reading of subjectivity should not be heard as a 'substantialist' conception that 'reinforces a liberal conceptualization of subjects and power as standing in a relation of externality' (Zanotti, 2013: 289). As much as unique, Arendt sees human subjects as intersubjectively constituting. She acknowledges the shared attributes through which we exist socially by the term 'what we are' (gender, race, age, ableism, class, etc.). Hence uniqueness is only one aspect of humanity, yet as important regarding political agency as 'what-ness' that is typically emphasised in critical research (e.g. Sayer, 2005; Ehrkamp, 2008; Hines, 2013; Lobo, 2014). In short, even if I am a woman and wish to be identified as one, I am not just any woman who can be recognised by some general terms, but the particular gendered person I feel to be (cf. Taylor on universal vs. particular and singular recognition, see Laitinen, 2002: 470). Arendt's analytical division between 'who' and 'what' makes clear why intersubjective socialisation inherently includes political dimensions. Human becoming is 
never a neutral, predefined developmental process-a top-down structured progression that leads to full humanity, i.e. adulthood—but part of ongoing struggles of 'coexistence and association' by which communities and societies exist (Arendt, 2005: 93, for similar readings in psychology see Hollway, 2006). Hence people's contested, experiential and contextual relations are focal in the maintenance and transformation of political life that occurs in 'the space where I appear to others and others appear to me [...] a space between the participants which can find its proper location almost any time and anywhere' (Arendt 1958: 198). This means that "politics is not something that grows out of predefined (ontological) notion of the political; instead politics takes place in relation to the place where its state of affairs is ontologically settled" (Joronen and Häkli, forthcoming, emphasis in original).

This reveals the phenomenological undertone of Arendtian philosophy as well as its acknowledgement of spatial relationality. The above quote from Arendt is part of her description of the 'polis', a political reality appearing particularly to each of its subjects yet existing only as shared. The concept is true to Mead's (1934:271) idea of communality: 'The question whether we belong to a larger community is answered in terms of whether our own action calls out a response in this wider community, and whether its response is reflected back in our own conduct.' As an attempt to spatialise political agency further on these grounds, I have refined the idea of polis from a topological perspective, together with Jouni Häkli ((Kallio and Häkli, forthcoming, see also Häkli and Kallio, 2014):

Polis is a relational space that bundles together people, issues, events, ideologies, places and objects, here and there, now, before and in the future. It is a constitutive 
context for people's view of themselves and (significant) others, influencing their understandings, awareness, and attentiveness and thus shaping them as political subjects. Polis is neither randomly constituted nor does it follow a singular spatial logic, such as territoriality, network, or 'flatness'. Its constituents are brought together by matters that gain importance in polis - issues that politicize and are politicized in a given geosocial realm - making it a dynamic space with a constantly changing shape and composition.

Understood this way, polis is the lived world that both conditions and enables political formation and activities. People are situated in their geosocial realms in particular ways, yet always relationally, which professes how human beings are concurrently intersubjective and unique. Consider the previous example to see how the politics of coexistence and association in such relational worlds may unfold: By living my life as the gendered person who I feel to be and encountering others with my conception of gender, I take part in negotiations over gender in my lived world. As this agency is primarily nonreflexive and only secondarily a matter of conscious choice (cf. Hollway, 2001: 43; Brown and Thomas 2014; Lobo, 2014), I have expressed my experiential gender for as long as I have been identified as a gendered subject in the geosocial realm where I am situated-that is, always. Thus, I exist as a gendered subject in the polis that exists to me, and I can take part in gender struggles only in this world that recognises me as a political subject.

The Arendtian conception of subjecthood as embedded in polis is fruitful for the exploration of political formation as it acknowledges children as already political situated 
subjects, instead of 'non-political becomings' who play no part in their own constitution and in what happens around them. Emphasising active agency, this approach encourages tracing situations in which children find themselves rightly identified from their personal perspectives or in which their experiential existence is questioned, as part of the politics of coexistence and association at play in their lived worlds. The next section frames these formative moments as occasions of (mis)recognition.

\section{Contextual recognition}

Recognition is a social theoretical concept inspired, most importantly, by the works of Charles Taylor (1994) and Axel Honneth (1995). As an ideal, it refers to a constitutive force that brings about good things in human life. If simplified, by recognising each other correctly people make life more ethical. Unsurprisingly, this idea has appeared to appeal most of all to identity political research, in a wide disciplinary range-for instance, in the study of gender politics (Hines, 2013), racial politics (Snyder, 2012), class politics (Sayer, 2005) and sexuality politics (Connell, 2012).

During the past fifteen years or so, a number of scholars have set out to criticise the underlining principles of identity-based recognition by drawing attention to its unpleasant ramifications. This interdisciplinary discussion, oftentimes referred to as the "ethics and politics of recognition debate', has presented an important turn in the theories of recognition. To move beyond identity categories, Fraser (2000), Cornell and Murphy (2002), Heyes (2003), Markell (2007), Deranty and Renault (2007), Warnke (2007), McNay (2008), Noble (2009), Connell (2012) and Snyder (2012), among others, have called for more intersectional and less categorical approaches. Instead of downgrading 
the importance of general social markers that position people differently in their communities and condition their agencies, they have sought to broaden the scope of recognition. By and large this debate-which certainly is not univocal but includes plenty of variation and even contrary suggestions-has addressed contextuality as imperative to the processes of subject formation and social life.

Discussing the dangers of too fixed a reading of recognition, Noble (2009: 877) points out that "we may lose sight of a more nuanced articulation of their lived experiences that engages with the complex sociability of their lives, involving a more diverse array of facets of identification'. He notes that categorical recognition involves the risk of '[collapsing] complex forms of situated subjectivities, accomplishments and aspects of 'character' [...] into a straitened argument about the reproduction of gender and racial inequalities rather than explore the ways in which these forms of social being entail multiple sources of esteem in everyday life'. Joining Markell (2003) in his Arendtinspired theorisation, Noble (2009: 888) suggests an analytical move from recognition to acknowledgement "which is less about respecting people for what they "really are", than ensuring that no-one is reduced to a caricaturing of identity for the sake of some broader political project'. Crossley (2001: 43), following Mead, goes so far as to argue that 'recognition that is not struggled for is not due recognition'.

To me, the major point of interest in this line of thought is its approach to subjects as context specific and variable in space and time. What there is to be recognised does hence not exist in general and cannot be known in abstracto. Only the subjects involved may know and term the 'stakes' of recognition and what feels 'right' or 'wrong' in a given situation, yet including their agencies as conditioned by the geosocial realm where they 
dwell (polis). This means that misrecognition often stems from generalising and categorical attitudes, if not from intentional diss-recognition. The methodological approach opening from this idea, however, does not provide direct analytical tools for studying political subjects or their formation. As the essence of the subject's 'who-ness' (e.g. experiential gender) is its inarticulate existence, it much harder to study than the subject's 'what-ness' (e.g. positioning with regard to gender categories). This largely explains why most research on political subjects focuses on socially constituted subject positions and identity constructions.

To recap the dilemma that the following analysis seeks to exceed: Placing analytical emphasis on generally identifiable identities highlights the relations of relative difference (raced, gendered, aged, classed, etc. subjects) at the expense of relations based on relative equality (subjects as particular persons) (Arendt, 2005: 96; also Markell, 2003: 35-36). Thus the uniqueness of political subjects receives little attention and the social dynamics of political living become noticed only partially, which may lead to biased understandings and to misinterpretations concerning political subjecthood.

\section{Mundane encounters, political outcomes: Intergenerational recognition at play}

Differently aged people may encounter each other practically anywhere and intergenerational relations are established and practiced in all kinds of situations (Vanderbeck, 2007). They take various forms, involve different levels of intensity and are more intentional at certain times than at others. I have explored intergenerational recognition under three themes, namely public, institutional and familial life. The following sections present findings related to two aspects that many of the participants in 
my study portrayed as particularly important in their daily lives and for their social existence: care and respect. First, I will discuss how positive recognition works as a driving force in familial intergenerational caring relations. Then I introduce experiences of respect in public encounters with adults.

\section{Intergenerational familial care}

The most common context for discussing intergenerational relations in my study was familial life, the foremost venue that people from all age groups typically bring up (Vanderbeck and Worth, 2014). The 'ordinary complexity of kinship', a splendid formulation by Mason and Tipper (2008: 443), rightly describes my participants' familial lives (see also Kallio, 2016b). Their close families included different configurations that ranged from two-parent nuclear families with two children to single-parent, two-person households to two households based in different cities with three to four parents, and beyond. Relatives living near and far, 'friend families', neighbours, pets and personal friends' families were presented as important associates-sometimes even more so than those regarded as 'real family'.

Familial recognition was often described as a mutual process that did not just happen to them but unfolded as an outcome of shared experiences and practices. One distinctive aspect in these strongly agential relations was care. From the intergenerational point of view, caring is particularly interesting due to its spatio-temporal dimensions. Caring agency is acted out subjectively and is meaningful to those involved when practiced. Yet it is not individualistic nor detached from (familial) pasts and futures. Although the practices of care can be singled out from the flux of everyday life-as single acts 
performed by certain individuals or groups, taking place at particular sites, in specific moments, with direct impact - they are always embedded in the contextual relations constitutive of these activities (cf. Mitchell and Elwood, 2013).

The quiddity of care is fluidity: it flows through people, animals, nature and artefacts, building ties that are not based on rationality or personal benefit but on maintaining, continuing and repairing something important (Bartos, 2012). This flowing does not, however, come about without practitioners. I appreciate caring humanistically as purposeful human activity with motivation in caring for matters that appear as important, in the polis 'that is shared by many people, lies between them, showing itself differently to each and comprehensibly only to the extent that many people can talk about it and exchange their opinions and perspectives with one another, over against another' (Arendt, 1995: 128, emphasis in original). Politics of care hence 'arises in what lies between men and is established as relationships', which makes it essentially contextual and multidimensional (Arendt, 1995: 95, emphasis in original).

Honneth $(1995: 105,95)$ sees that intimate caring relations provide people opportunities to 'be at home in the other'; they involve practical forms of love where 'recognition itself must possess the character of affective approval or encouragement', to provide for self-confidence. I agree with this idea, in line with Warming (2015: 250), who stresses that the importance of caring relationships continues throughout the lifecourse as 'the need for emotional recognition goes beyond early childhood' (see also Hollway, 2006). This notion draws attention to children's active caring agencies. Concerting the findings by Bartos (2012), Marshall (2013), Evans (2014) and Tarrant (2015), my analysis indicates that children are not only care-receivers but also care-givers 
with active and effective roles in mundane caring networks, and their caring attitudes and practices are often noticed by their significant others of kinship, either explicitly or implicitly .

Mutual caring relations between close family members were portrayed by most of my participants. They noted that helping out in household chores, babysitting and cheering up the parents by cooking and baking, for instance, receive positive acknowledgement. 'Mom implies her gratitude for help by words but also otherwise', stated one of fifth graders. Children's soothing and peacekeeping practices may also be part of family life. The same girl provided a detailed description about how she observes and sometimes intervenes in her parents quarrels, to bring back the peace and to maintain it: 'When the fight is over, I go to the same room with them to make sure that it does not begin again [...]Dad calms down when I cuddle close to him.'

Many found visiting their grandparents personally rewarding. As they had become eminently aware of the special meaning of their visits, they were determined to keep up these relations. Some linked other amiable relations, like friendships, to the visits, which made it easier for them to include grandparents within their rhythms of life. One of the ninth graders told how she has taken the habit of staying regularly overnight with her granny who lives alone, while visiting her best friend living close-by (see also Kallio, 2016b: 9). This makes it easy for her to provide a helping hand in taking care of the house and the garden. Echoing the same spirit, the next interview piece with another ninth grade girl demonstrates how familial caring relations may appear to young people: 
$M e$ : In your family, do you feel that everyone takes care of each other or is it rather so that adults take care of the kids?

Participant: Well, I think that everyone takes care of everyone. If like my mom has some troubles I listen to her and try to help out as best as I can. And a big part of our life is granny and grandad from my dad's side, and granny from my mom's side. They also belong to our family and they are told about things.

$M e$ : Right. How do you see your own role in your family, including all these people you mentioned? What kinds of things can you do for the family, like helping out? Participant: Well, I usually listen to everyone and we talk about all kinds of things ... Yeah, I listen, and then it is usually me who knows things like mobile phones and such. Granny, for instance, says [changes voice]: 'Can you come stop by now that this TV is not working again?' [convivial laugh] And then I go over. I help in those kinds of stuff.

$M e$ : Okay. Is it important to you?

Participant: Yes. Because I like to help people, I can see that they get happy from it.

Caring does not, however, seem as effortless in all cases. Some kids did not always enjoy the visits with their grandparents, yet they also insisted on their importance. These situations did not resemble 'hidden care work' that may place girls, typically, in subordinate positions (e.g. Evans, 2014), but rather commitment to familial caring relations. To take one example, one of the fifth graders told how her parents, along with the extended family, had developed strained relations with her granny. She and her little sister were the only relatives who kept up the relations with her. Even if their visits were 
not always pleasant and led to all kinds of situations, she was well aware of their importance to the granny (for a detailed analysis of this case, see Häkli and Kallio, forthcoming).

In this and similar cases, intergenerational recognition worked as a driving force that defined the children's visits as particularly welcomed acts of care and buoyed them to act for their families. They were empowered as influential members of their families, as 'aged subjects' instead of children in the categorical sense. In Snyder's (2012) words, at play was a 'politics of multivalent recognition' not based on identity with a single definitive content (what-ness) but on diverse ways of being a child (who-ness). In addition to such first-hand attitudes and practices, other forms of caring were acknowledged — but also diminished—in kinship encounters. These could be related to pets, friends, natural environments, conflict societies, underprivileged people, family house or school life. Taking care of one's dog was one common feature brought up in this light. Consider the experiences of three fifth grade girls.

One of the girls had been thinking about a dog of her own since she was six years old. Nine months before we met her wish had finally fulfilled. Before that, the parents has tested her by giving her the responsibility for their older dog for a month. After proving her persistence and competence, she was made fully responsible for the acquired dog. Now she organises her days from early morning to late evening from the perspective of a dog owner and takes great pride of this responsible role that her family has approved of. In contrast with this case, another girl who also wanted a dog had been denied the possibility. Refusing to give up her awakened desire to care for a pet and to show her family how serious she was about the matter, she had created a test of her own by starting 
to care for a dog-shaped soft toy. 'I kinda perform that it is my real dog so that I could get a dog.' In this purpose, she had bought him 'real dog biscuits, two real bones, a leash, a rubbery plaything and a ball'. The plan seemed to be working as her granny was considering a dog that she could care for.

Some children told about complete ignorance towards their caring agencies, like a third animal lover from the same class who had recently experienced a loss of pet. The dog had been adopted by the family when she was four years old, as an abandoned pet. After moving to an apartment, just some months back, the family could not keep her anymore. They gave the dog to a 'foster family' with her mother's sister whom they implored to let them know if she gave any symptoms of passing. The move seemed wrong from the beginning: 'They were quite selfish. I could not take her out after she moved there. I was not even allowed to stroke her anymore.' It had still come as a shock to hear that the dog had been put down during the summer holidays in total indifference and silence.

In these and other dialogical biographies, (mis)recognition related to caring could be identified mostly from the ways in which the participants presented their cases. They spoke and wrote affectionately about these situations and introduced memorable moments with pride and gratification. In the interviews their voices echoed a sense of self-approval and self-competence. Brief smiles and contented grins crossed their faces. Lowered tone of voice was used as well as heightened expressions. Smileys, hearts and other drawings were made in essays and on the maps in places where dear people lived or where something specific had happened. 
These expressions imply that the participants told us as much about themselves as political subjects through their caring agencies as about the discussed subject matters. I learned that most of them considered themselves valued persons and capable members in their families. Situations that feed into such experiences can be fleeting moments, such as father apologising for her daughter, or long-term activities, like an informal skating hobby shared by a daughter and a father. These experiences were reflected upon by a fifth grader in a written story, one among many where a memorable event was revisited to tell about mutually respective relationships that acknowledge "complex forms of situated subjectivities', to use Noble's expression (see section 'Contextual recognition', also Cornell and Murphy, 2002).

In addition to 'ordinary' situations barely discernible from the ebb and flow of familial life, we discussed critical events that had made our participants feel as important persons. Making difficult decisions together was one way in which care unfolded in these situations. One of the ninth grade girls told about a familial decision to place her elder brother into a youth detention centre. He suffers from the Asperger syndrome and has difficulties in controlling himself, which had led to repeated offences with unintended consequences. Importantly to her, the conclusion that they could no longer look after him was made by 'us as a whole family that desperately loves him'. Another distressing situation was described by a twin-girl who had been invited to represent her country in a sport that she practiced with her sister. The sister was not included in the team, which created a terrible situation for them. She could feel the pain her sister tried to hide and she also knew that giving up the opportunity would only add up to her contradictory feelings: 'Ifelt like I had made a mistake because they asked me.' Fortunately, the parents were 
sensitive to their anxieties and did not leave her alone to decide on the matter. Together the sisters and the parents talked it though and came to the thought that 'it is, after all, the national team, so cannot really be passed'. Both of these affective situations can be seen as formative moments that provided for the girls' understandings about themselves and others as intergenerationally situated subjects, with capacities to act together (cf. Bartos, 2012; Marshall, 2013).

The experiential accounts analysed in this section indicate how children's 'familial significant others' may recognise their agencies adequately - in ways that the child finds situationally appropriate - and thus shape them into caring political subjects. The next section introduces how recognition plays out beyond the family, in the 'public lives' that children and youth lead.

\section{Intergenerational respect in public encounters}

Most children and young people in my study could move about freely in their hometowns if their parents knew approximately where they were and when they would come home. Nearly all of them went to school and to other activities on their own or with their friends or siblings, on foot or by bike or bus, and during the afternoons they could hang out wherever they wanted to. This freedom tells much about the everyday practice of family life in Finland. Despite the risk and worry talk that dominates the national media and child and youth policy, public space is considered relatively safe. In many families the kids are trusted as 'smart girls and boys' who know how to act appropriately and take care of themselves and each other. 
Knowing this it was quite surprising that the descriptions of public life rarely brought up intergenerational encounters. People other than those in their company were not usually separated out from the rest of the environment. Our queries about adults' ways of treating them were typically met by bemused looks and blunt remarks, such as 'like normally', which were sometimes accompanied with explanations like 'we don't do anything that would require "treatment"'. These expressions indicate that contacts with adults happened frequently in public space but usually in ways that did not raise particular awareness, which proves that most of the time they did not find themselves publically misrecognised.

Instead of adults, we discussed extensively where urban children and youths spend time. Their 'everyday public' included commercial areas (downtown, malls, shops), public transportation (buses, trains), hobby places (sports arenas, horse stables, swimming halls) and neighbourhoods (parks, woods, fields, streets) ${ }^{\mathrm{vi}}$ These were visited in the company of friends, family members, teammates and pets, but also alone. As we talked about these activities I found that experiences related to 'respect' allowed access to some distinct intergenerational relations and agencies.

I approach respect as a broad category, connecting it with both rights/self-respect and solidarity/self-esteem, as outlined by Honneth (1995). Drawing from Hegelian ethics, he talks about 'the social dynamics of disrespect' as a feature of civil societies in which 'moral injustice is at hand whenever, contrary to their expectations, human subjects are denied the recognition they feel they deserve [leading to] feelings of social disrespect' (Honneth, 2014: 71). In my reading, the political subjectivities at stake here are based on personal stances, formed by each subject in relation to the social positions that the polis 
proposes to her/him, through its intersubjective dynamics (Häkli and Kallio, 2014: 188). That is, being (mis)recognised as a child rests upon one's personal experience of being a particular child who (sic) is different from all other children (cf. Brown and Thomas, 2014; Lobo, 2014). The adequacy of recognition is hence always assessed from experiential positions and cannot be generalised to other situations or to other individuals.

When visiting shops and restaurants and using public transportation, my participants did not wish for particular attention with regard to their age. They rather hoped for equal treatment along with other people (cf. Elwood and Mitchell, 2012). Many of them stressed that they did not mind if they were met as children or youth as long as their presence as customers, city dwellers and other public figures was respected somewhat appropriately. To be treated 'like normally' was something they expected of adults as they themselves tried to fulfil general expectations in public space. Similar findings have been made in a number surveys and studies exploring Finnish youths' experiences in/of public space (e.g. Lampela et al., 2016).

Mundane acts of respect take often nearly imperceptible forms that are hard to articulate or ask about. The bus driver returning one's hello and taking the curves smoothly was mentioned as something that 'makes you feel good', and vice versa, the drivers who do not seem to care about the passengers are disapproved of. Some of the participants explained that in public space privacy is particularly important. They conveyed how it is nice to sit in the bus, browse around shops and hang around in the neighbourhood 'when no one bothers you'. Also, when getting together with friends and meeting with other youths at shopping malls and parks, it is appreciated if adults do not pay too much attention to young people's presence (cf. Pyyry, 2016). 
Related to this form of public life, negative experiences were expressed by some boys who had gathered in large groups in their neighbourhood during summer evenings. They were so young at the time that this was basically the only place where they could spend time with their parents' permission, outside of their homes and organised hobby places. Yet they had to change the place all the time because 'someone got disturbed'. What they respected was tolerance to their presence in the neighbourhood that offered a place to spend time together safely (cf. Vanderbeck and Johnson, 2000; Crossley, 2001). The same could be found in institutional contexts. One of the girls provided a lengthy description about the problems caused by a teacher who had interfered with their friendships that 'are not really her business'. Among other things, this points to the blurry lines between intimate, public, and institutional spaces that imbricate in the everyday environments where children and young people dwell (for more analysis on intergenerational recognition in institutional contexts, see Kallio, 2014b).

These reflections imply that intergenerational respect may take the form of sharing space, where mutual respect is built by staying apart and thus allowing everyone the right to be present in a given situation or place (cf. Ehrkamp, 2008; Brown, 2012). People from different generational positions can recognise each other appropriately by 'not encountering'; by sharing space in ways comfortable enough to everyone. This kind of respective coexistence that includes the acknowledgement of what Noble (2009) calls complex sociability is perhaps not as rewarding as some other forms of recognition, yet it may be as eminent to the youths who are developing as political subjects. 
One illuminative example of explicit respectful intergenerational relations was given by a fifth grade boy. He was perhaps more attuned to this aspect of social life as he was bullied in school and suffered from the prolonged situation that no-one seemed to be able to change. He told us about his hobby called Airsoft. At first sight, it may not seem like an activity recommended for children.

\section{Me: What is it?}

Participant: Its about shooting balls of this size [shows with fingers], with guns that look exactly like real ones. If there was one of those here, I could not say if it is a ball-gun or a real gun, they look so real.

Elina: What do you shoot with it, is it target shooting or what do you --Participant: Each other!

Elina: Each other, ok.

Participant: We play war in the woods and try to shoot each other with them.

It appeared that Airsoft is not an organised hobby but a non-regular leisure activity bringing together individuals and groups interested in playing war. They gather outside the city, bringing their own equipment, in desolate areas where the game can be played safely and without interference. The basic idea is to fight until one of the parties has demolished the other and thus won the war. Most of the players are teenagers or young men but also boys as young as nine years old had taken part in the activities with our participant. When we asked about how the older guys treated the younger ones, he expressed with enthusiasm: 
Participant: I don't know a place where children are taken into account and included so well. There children are not singled out in any way, we are involved just like anyone, in planning and everything.

Elina: Do the children who are there regard you differently from the adults who are there?

Participant: Not really.

These kinds of mundane respectful situations may provide children and youth experiences of equality and belonging that they can hardly put in words, manifesting 'equal dignity of persons' (Cornell and Murphy, 2002: 438). In addition to this, the example makes a point that the contexts where children feel respected may not always be such that adult authorities consider appropriate or supportive of their wellbeing. This boy's biography underlines how children may feel constantly disrespected in some apparently 'good' spaces and, respectively, respected in 'bad' ones. Whereas the school had failed to offer him an environment where he could feel as a morally accountable active subject (providing for self-respect) or as a unique person with special characteristics (promoting self-esteem), some young men interested in reality war games had acknowledged him as a skilful and trustworthy community member. Similar situations were described by boys who were intensely involved in gamer communities where they felt empowered and respected, yet adults gave little appreciation to these activities, people or relationship, especially when in question were web-based, multiplayer role-playing games including violence. 
Other examples of overt (dis)respective encounters with adults were presented in the context of customership. One of the fifth graders shared with us her experiences as a customer, describing in-depth how either pleasant or unfriendly service made her feel happy or frustrated. She had started to pay specific attention to this matter because she felt disturbed when salespersons, waiters or officials did not meet her as a proper customer. If she, as a child, has made an effort to learn how to act appropriately in various public situations and run errands on her own, why would adults not respond to her attempts? In her quest for mutual intergenerational recognition-clearly respect for her rights as an equal community member — she had started to express her irritation by giving critical feedback through customer feedback systems as in face-to-face contacts she could not claim an even position with the adults in question.

Another fifth grader had found particularly convenient a situation where a salesperson had provided adequate information about a product and told the terms of the deal pertinently, after many contrary experiences. Politeness, in particular, seemed important to this boy, which connects his experiences with equality in the meaning of solidarity rather than rights. He considers it so valuable that even with the people who are always rude he tries to keep up the good spirit: 'I just try to be cheery'. I asked him to elaborate a bit more on this.

$M e$ : How do adults regard youth? What do you consider nice behaviour and what rather silly?

Participant: Well it's quite unfair if like, in a shop, adults just jump the queue, over the kids, like they did not notice you at all. Such things. And sometimes when there is 
like an odd counter, the salesperson just takes adults first even if I had been there for much longer. Then that is smart when someone says, 'He was here before me', whereas some people say nothing.

$M e$ : Right. So it is equal treatment that you consider important?

Participant: Right.

What this discussion professes is that children can distinguish between different dimensions of recognition, including inconsiderate nonrecognition, unintentional misrecognition and purposive disrecognition, in contrast with active positive recognition (cf. Baines, 2015). Even if the boy does not articulate it explicitly, he was quite clearly aware that in a shopping queue adults do not accidentally bypass children because of their invisibility and that children's small size is not the reason why salespersons may serve them unfairly. He did not describe the people as merely inconsiderate that may be the case when 'some people say nothing', which can be interpreted as acts of nonrecognition. As adult customers use their superior positions to get to the checkout first, they do not perhaps mean to mistreat children as inferior but, anyhow, come to deliver this message, thus practicing misrecognition. The portrayed salespersons' actions, instead, can be seen as nothing but what I call purposive disrecognition, to continue Taylor's (1994) conceptualization, as the selective treatment of customers is always unacceptable professional practice. In contrast to all these, the adults who seek to correct mistreatments represent just agency to this boy, i.e. positive recognition.

This section has discussed mostly fleeting encounters between children, youth and adults, taking place in very mundane situations in which people coexist and associate 
with each other. In addition to lasting and intimate relations that certainly are significant in the processes of intersubjective socialisation, I reckon these public encounters as highly influential to political subject formation. By meeting young individuals and groups as particular persons and equal community members people from older generations can support their self-respect and self-esteem. Respectively, by diminishing them as codwellers adults imply that all people should not be treated equally, which signals that some people — as individuals or members of a certain group—are inferior to others.

The idea of intersubjective socialisation includes that children take actively part in their own political constitution. In disrespectful situations this means forming a personal stance towards the subject position being offered, instead of unquestionably adopting the proposed role and performing expectedly. Children may therefore identify negative attitudes as unfairness that should not take place, which may strengthen their ethical conceptions of equality and lead to requests for rights-based recognition. This became apparent with those participants with whom we discussed respect openly, including the boy who plays Airsoft and is bullied in school: he wants to become a police officer so that he could help and protect other people.

Yet alternative stances are also established. Adults' disrespectful agencies may encourage evaluative thinking and bolster children's feelings of superiority in situations where someone else is in a weaker position. I came across with such political development especially when politicised issues like ethnic differences, panhandling and national sovereignty came up, or when we talked about hierarchies and social positions in school life. Making use of powerful positions is not strange to children either. Moreover, submission to subordinating subject positions is another possible outcome of 
disrespectful intergenerational encounters. Accepting that I, as the person who I feel to be, do not compare with other people, leads to negative tones in the child's sense of self.

These dimensions of youthful agency that the analysis brought up, among others, made me consider, on one hand, the importance of noticing that becoming political is not the same thing as becoming critically aware, and on the other hand, that children learn about political life primarily from elsewhere than schoolbooks or news that seek to invite critical thinking. It is social life, unfolding as a polis that enables and conditions subject formation and people's activities, that shapes human beings into political subjects. This paper argues that intergenerational relations lie at the heart of this mundane political life.

\section{Towards understanding mundane politics in intersubjective socialisation}

This article has discussed the role of intergenerational recognition in subject formation and political development. By exploring some encounters that children and young people have in their mundane environments with different adults, I have sought to make visible fleeting moments as well as long-lasting relations in which political subjects 'take shape' during the early years. I have concentrated on two themes that surfaced in my study: care and respect.

The analysis suggests, first, that the recognition of youthful, caring agencies in familial relations builds children and young people into subjects who find themselves important to other people and capable of contributing to their communities. In Honneth's terms, this provides for their self-confidence as political subjects. Similarly, overlooking children's commitments to care is hurtful and may have negative effects on their sense of self. Like other forms of agency, caring is experienced and practiced in a variety of ways. 
Thus, its acknowledgement requires situational sensitivity. Second, I have proposed contextual respect as a focal aspect in encounters between children, young people and adults. By meeting young individuals and groups in respectful and disrespectful manners, adults are not only stating their opinions about them but also implying attitudes concerning equality in general. Through the processes of intersubjective socialisation, these attitudes, which may be conveyed also unintentionally, inform children's and young people's conceptions concerning themselves, other people and the worlds where they live influentially. Giving, receiving and denying respect in intergenerational relations is hence related to both rights and solidarity, in the Honnethian framework. As a whole, the analysis emphasises children's active roles in intergenerational relations, including potential for alternative present and future political agencies.

Theoretically, the paper has introduced an Arendtian conception of political subject formation as embedded in topological polis, arguing that people become political by coexisting and associating with their significant others through geosocial relations. Contrary to traditional approaches, I have analysed political socialisation as a dynamic process that involves children and young people as active players, introducing the concept of intersubjective socialisation to underline this aspect. The agencies of 'significant others' who form the other important players in these processes have been discussed in terms of contextual recognition. The approach acknowledges the specificity of human subjects in political life, which places it among humanistic approaches.

Methodologically, I have argued that in the analysis of political subject formation it is vital to distinguish between identity-based and subjectivity-based recognition as the two lead to different—even contrary—outcomes. The analysis has sought to demonstrate how 
it is possible to identify trajectories of intersubjective socialisation by tracing experiential relations through which children and young people learn to position themselves and others in their lived worlds — and become shaped as relational yet unique political subjects. Contradictions between categorical and experiential characteristics become apparent most clearly in how children feel about and see themselves and others as 'aged subjects', in different spatio-temporal situations.

In conclusion, I wish to make two claims. First, I think that 'political becoming' should be studied much more extensively than is done today. In human geography, as in other social sciences, the development of political agencies receives hardly any attention whereas the practice and government of political agencies are over-represented in the research. Considering some topical issues, such as extremely violent forms of terrorism and the transnational refugee movement, it would be crucially important to understand how political agencies take shape and are shaped during early years, and how children and young people could be recognised respectfully as persons who are important to other people and capable of contributing to the common good through caring agencies. In these challenging enquiries, an enlivened conception of socialisation could be found helpful.

Second, I consider intergenerationality a fruitful concept for approaching political agency as relational and non-substantial. With its inherent temporalities, it involves various dimensions of past, present and future, thus contesting the idea that politics is practiced by autonomous subjects who act alone here and now. At the same time, intergenerationality includes the fact that change is reliant upon new political subjects who enter geosocial relations and continue them in their own orientations, attitudes and activities. By studying how different kinds of political agencies are negotiated, 
reformulated, adopted and rejected in long-standing intergenerational relations, as well as in fleeting moments in which people from different generational positions encounter each other, we could learn about political agency as concurrently subjective and shared.

\section{Acknowledgements}

I am grateful to the editors of EPD, and particularly Mary Thomas, for the efficient and skilled publication process, and to the three anonymous referees for their committed and careful engagement with the paper. I also wish to thank the Academy of Finland for financially supporting this work (grant SA258341), and the Space and Political Agency Research Group (SPARG) at the University of Tampere for an inspiring research environment.

\section{References}

Arendt H (1953) Ideology and terror: A novel form of government. Review of Politics 15(3), 303-327.

Arendt H (1958) The Human Condition. Chicago: University of Chicago Press.

Arendt H (2005) The Promise of Politics. Krohn, J. (ed) New York: Schocken Books.

Baines EK (2015) “Today, I want to speak out the truth": Victim agency, responsibility, and transitional justice. International Political Sociology 9(4): 316-332.

Barnett C (2012) Situating the geographies of injustice in democratic theory. Geoforum 43(4): 677-686.

Bartos AE (2012) Children caring for their worlds: the politics of care and childhood. Political Geography 31(3): 131-194. 
Bosco F (2010) Play, work or activism? Broadening the connections between political and children s geographies. Children's Geographies 8(4): 381-390.

Brown K (2012) Sharing public space across difference: Attunement and the contested burdens of choreographing encounter. Social and Cultural Geography 13(7): 801820.

Brown A and Thomas M (2014) " $\mathrm{i}$ just like knowing they can look at it and realize who $\mathrm{i}$ really am": Recognition and the limits of girlhood agency on MySpace. Signs: Journal of Women in Culture and Society 39(4): 949-972.

Connell B (1987) Why the "political socialization" paradigm failed and what should replace it. International Political Science Review 8(3): 215-223.

Connell R (2012) Transsexual women and feminist thought: Toward new understanding and new politics. Signs 37(4): 857-881.

Cornell D and Murphy S (2002) Anti-racism, multiculturalism and the ethics of identification. Philosophy and Social Criticism 28(4): 419-449.

Crossley N (2001) Citizenship, intersubjectivity and the lifeworld. In: Stevenson N (ed) Culture and Citizenship. London: Sage, pp. 33-47.

Deranty JP and Renault E (2007) Politicizing Honneth's ethics of recognition. Thesis Eleven 88(1): 92-111.

Dikeç M (2013) Beginners and equals: Political subjectivity in Arendt and Rancière. Transactions of the Institute of British Geographers 38(1): 78-90.

Ehrkamp P (2008) Risking publicity: Masculinities and the racialization of public neighborhood space. Social and Cultural Geography 9(2): 117-133. 
Elwood S and Mitchell K (2012) Mapping children s politics: Spatial stories, dialogic relations and political formation. Geografiska annaler: Series B, Human Geography 94(1): 1-15.

Evans R (2014) Parental death as a vital conjuncture? Intergenerational care and responsibility following bereavement in Senegal. Social and Cultural Geography 15(5): 547-570.

Fraser N (2000) Rethinking recognition. New Left Review 3(May-June): 107-120.

Habashi J and Worley J (2009) Child geopolitical agency: A mixed methods case study. Journal of Mixed Methods Research 3(1): 42-63.

Häkli J and Kallio KP (2014). Subject, action and polis: theorizing political agency. Progress in Human Geography 38(2): 181-200.

Häkli J and Kallio KP (forthcoming). On becoming political: studying the political ordinary. Theory and Society [in process]

Heyes C (2003) Can there be a queer politics of recognition? In: Fiore RN and Nelson HL (eds) Recognition, Responsibility, and Rights: Feminist Ethics and Social Theory. Lanham: Rowman and Littlefield, pp. 53-66.

Hines S (2013) Gender Diversity, Recognition and Citizenship: Towards a Politics of Difference. Bakingstoke: Palgrave Macmillan.

Hollway W (2006) The Capacity to Care. London and New York: Routledge.

Honneth A (1995) The Struggle for Recognition: The Moral Grammar of Social Conflicts. Cambridge: Polity Press.

Honneth A (2014) Disrespect: The Normative Foundations of Critical Theory. UK: Polity Press. 
Joronen M and Häkli J (forthcoming) Politicizing ontology. Progress in Human Geography [in copy editing]

Kallio KP (2007) Performative bodies, tactical agents and political selves: rethinking the political geographies of childhood. Space and Polity 11(2): 121-136.

Kallio KP (2014a) Rethinking spatial socialization as a dynamic and relational process of political becoming. Global Studies of Childhood 4(3): 210-223.

Kallio KP (2014b) Intergenerational recognition as political practice. In: Vanderbeck R and Worth N (eds) Intergenerational Space. London: Routledge, pp. 139-154.

Kallio KP (2016a) Becoming geopolitical in the everyday world. In: Benwell M and Hopkins P (eds) Children, Young People and Critical Geopolitics. Aldershot: Ashgate, pp. 169-186.

Kallio KP (2016b) Living together in the topological home. Space and Culture. [OnlineFirst March 2016]

Kallio KP and Häkli J (2011) Are there politics in childhood? Space and Polity 15(1): $21-34$.

Kallio KP and Häkli J (2013) Children and young people's politics in everyday life. Space and Polity 17(1): 1-16.

Kallio KP and Häkli J (forthcoming) Geosocial lives in topological polis: Mohamed Bouazizi as a political agent. Geopolitics [in copy editing]

Kallio KP, Häkli J and Bäcklund P (2015) Lived citizenship as the locus of political agency in participatory policy. Citizenship Studies 19(1): 101-119.

Kjørholt AT (2002) Small is powerful: Discourses on children and participation in Norway. Childhood 9(1): 63-82. 
Laitinen A (2002) Interpersonal recognition: A response to value or a precondition of personhood? Inquiry 45(4): 463-478.

Lampela P, Leppävuori M and Puomilahti I (eds) (2016) Hengailua, kohtaamisia ja yhdessä olemista: nuoruuden elementtejä ja työmuotoja julkisissa ja puolijulkisissa tiloissa. Kuopio: Nuorten Palvelu ry.

Leitner H and Sheppard E (2009) The spatiality of contentious politics: More than a politics of scale. In: Keil R and Mahon R (eds) Leviathan Undone? Towards a Political Economy of Scale. Vancouver: Ubc Press, pp. 231-245.

Lobo M (2014) Everyday multiculturalism: Catching the bus in Darwin, Australia. Social and Cultural Geography 15(7): 714-729.

Markell P (2003) Bound by Recognition. Princeton, NJ: Princeton University Press.

Markell P (2007) The potential and the actual: Mead, Honneth, and the "I". In: Van den Brink B and Owen D (eds) Recognition and Power: Axel Honneth and the Tradition of Critical Social Theory. New York, NY: Cambridge University Press, pp. 100-132.

Marshall D (2013) All the beautiful things: Trauma, aesthetics and the politics of palestinian childhood. Space and Polity 17(1): 53-73.

Marshall D (2015) Existence as resistance: Children and the politics of everyday practice in Palestine. In: Kallio KP and Mills S (eds) Politics, Citizenship and Rights. Vol. 7 of Skelton T (ed) Geographies of Children and Young People. Singapore: Springer, pp. 245-262.

Mason J and Tipper B (2008) Being related: How children define and create kinship. Childhood 15(4): 441-460. 
Matthews H, Taylor M, Percy-Smith B and Limb M (2000) The unacceptable flaneur: The shopping mall as a teenage hangout. Childhood 7(3): 279-294.

McNay L (2008) Against Recognition. Cambridge: Polity Press.

Mead GH (1934) Mind, Self, and Society. Ed. by Charles W. Morris. Chicago: University of Chicago Press.

Mitchell K and Elwood S (2013) Intergenerational mapping and the cultural politics of memory. Space and Polity 17(1), 33-52.

Mitchell K and Elwood S (2012) Mapping children's politics: The promise of articulation and the limits of nonrepresentational theory. Environment And Planning D: Society And Space 30(5): 788-804.

Noble G (2009) "Countless acts of recognition": Young men, ethnicity and the messiness of identities in everyday life. Social and Cultural Geography 10(8): 875-891.

Ortner S (2002) Subjects and capital: A fragment of a documentary ethnography. Journal of Anthropology 67(1): 9-32.

Pyyry N (2016) Learning with the city via enchantment: Photo-walks as creative encounters. Discourse: Studies in the Cultural Politics of Education 37(1): 102-115.

Ringmar E (1996) Identity, Interest and Action: A Cultural Explanation of Sweden's Intervention in the Thirty Years War. Cambridge: Cambridge University Press.

Rose G (1997) Situating knowledges: Positionality, reflexivity and other tactics. Progress in Human Geography 21(3): 305-320.

Sayer A (2005) The Moral Significance of Class. Cambridge: Cambridge University Press. 
Simonsen K (2013) In quest of a new humanism: Embodiment, experience and phenomenology as critical geography. Progress in Human Geography 37(1): 10-26.

Snyder G F (2012) Multivalent recognition: Between fixity and fluidity in identity politics. The Journal of Politics, 74(1): 249-261.

Staeheli L (2008) Political geography: Difference, recognition, and the contested terrains of political claims-making. Progress in Human Geography, 32(4): 561-570.

Strandell H (2010) From structure-action to politics of childhood: Sociological childhood research in Finland. Current Sociology 58(2): 165-185.

Tarrant A (2015) (Grand) paternal care practices and affective intergenerational encounters using Information Communication Technologies. In: Vanderbeck R and Worth N (eds) Intergenerational Space. London: Routledge, pp. 286-299.

Taylor C (1994) The politics of recognition. In: Gutmann A (ed) Multiculturalism: Examining the Politics of Recognition. Princeton, NJ: Princeton University Press, pp. $25-73$.

Uprichard E (2008) Children as being and becomings: Children, childhood and temporality. Childhood and Society 22(4): 303-313.

Vanderbeck R (2007) Intergenerational geographies: Age relations, segregation and reengagements. Geography Compass 1(2): 1-22.

Vanderbeck R and Johnson J (2000) “That's the only place where you can hang out": Urban young people and the space of the mall. Urban Geography 21(1): 5-25.

Vanderbeck R and Worth N (eds) (2014) Intergenerational Space. London: Routledge. Warming H (2015) The life of children in care in Denmark: a struggle over recognition. Childhood 22(2): 248-262. 


\section{Warnke G (2007) After Identity. Cambridge: Cambridge University Press.}

Zanotti L (2013) Governmentality, ontology, methodology: Re-thinking political agency

in the global world. Alternatives: Global, Local, Political 38(4): 288-304.

\footnotetext{
${ }^{\text {i }}$ Preventing children's marginalization through place-based participation (SA134949) and Political presence as a right of the child (SA258341).

${ }^{\text {ii }}$ In all empirical work an ethical research practice was followed, respecting the right of children and young people to decide whether or not they wished to participate in our research. In practice, this was done by letting the participant choose what they did and did not want to share with us. We considered the practice successful as some of them shared close to nothing with us whereas others provided rich enough data for individual case analyses. In addition to this, we sought informed consent from the participants' parents and acquired the pertinent institutional research permissions.

iii 'Plurality is the condition of human action because we are all the same, that is, human, in such a way that nobody is ever the same as anyone else who lived, lives, or will live.'

iv 'With each new birth, a new beginning is born into the world, a new world has potentially come into being'.

${ }^{\mathrm{v}}$ This finding is, of necessity, contextual, like all ethnographic findings are. Yet similar findings have been made in many studies, from different geographical contexts and with children and youth in various life situations, including those mentioned here.

${ }^{\text {vi }}$ Our participants considered commercial space, swimming halls, and other semi-public space as one of the most important venues of public life. Hence I have not separated these into a different category. For similar findings, see Matthews et al. 2000; Vanderbeck and Johnson, 2000; Pyyry, 2016.
} 